\title{
Encouragement of Early Academic Skills at Home during Early Childhood Period: Validity and Reliability Study of the EASYC Scale
}

\author{
H. Gözde Ertürk Kara ${ }^{1, *}$, Şeyda Kılıç Çoksoyluer ${ }^{2}$ \\ ${ }^{1}$ Early Childhood Education Department, Faculty of Education, Aksaray University, Turkey \\ ${ }^{2}$ Early Childhood Education Department, Institute of Social Sciences, Aksaray University, Turkey
}

Copyright $\bigcirc 2017$ by authors, all rights reserved. Authors agree that this article remains permanently open access under the terms of the Creative Commons Attribution License 4.0 International License

\begin{abstract}
The current study aims to perform the adaptation of the Encouragement of Academic Skills of Young Children (EASYC) Scale into Turkish. The study group was determined by means of the convenience sampling technique. A total of 124 students aged at 48-84 months were included in the sampling of the study. The data collection tools of the study are the Turkish Version of Encouragement of Academic Skills of Young Children Scale (ÇEABD) and the Home Literacy Activities Questionnaire used for criterion validity. In the analysis of the data, explanatory and confirmatory factor analyses, Pearson correlation analysis, descriptive analysis, item total correlation, and internal consistency coefficient calculation were used. As a result of the study, the ÇEABD was proved to be valid and reliable scale in the Turkish sampling. The mean scores taken by the children in the sampling from the reading and math dimensions of ÇEABD and their total mean score were found to be at the medium level. Thus, it can be argued that the parents of the children in the sampling moderately encourage them in activities related to letters and words, comprehension, formal math activities, informal math activities and activities related to games/toys sub-dimensions.
\end{abstract}

Keywords Early Childhood Period, Parent Participation, Early Academic Skills, Reading, Math, Encouragement of Academic Skills of Young Children, Validity, Reliability

\section{Introduction}

The early childhood period is a critical period in which the child is expected to be able to grow healthily, develop motivation for learning, construct rich language interactions, gain positive social emotional experiences, develop the ability to act independently and thus form the basis for their learning in the further stages of schooling. In addition to qualified early childhood education, the learning environment presented to the child at home by the parents is also very important for the child to achieve these goals [28]. At this point, it can be said that the child is not alone in the process of development and learning and that the adults in his/her close circle have a number of roles and responsibilities in this process. According to Vygotsky [39], one of the theorists working on the influence of the environment on the development of the child in the early childhood period, learning should be viewed as a social process rather than an individual process. In this process, the child's environment plays a critical role. The child acquires the knowledge, skills and behaviors that the society attaches importance to through the interactions established with the adults around him/her (family, teacher, etc.). In this process; as the child's first supporter, the parents are responsible for presenting an environment full of enhanced stimuli and providing guidance. The pioneer of the ecological systems theory, Bronfenbrenner [7] examined the environment in which the child lives by dividing it into levels. One of these levels, the microsystem is made up of the family, school and peers with whom the child establish direct interactions as they are closest to him/her and affects the child's social and academic development to a great extent. In the Early Childhood Education Program of the Ministry of National Education, which is adopted in our country, it is emphasized that parent participation and education is important considering the effect of the family, which is the primary environment of the child, on the development and learning. In this regard, it is aimed to ensure the continuity of the school by establishing qualified interactions at home in the early childhood period and to realize permanent learning in the child [28].

Through these interactions established in the early 
childhood period, early academic skills such as literacy and math required for the child to learn further are supported [4-15]. Literacy skills consist of subordinate skills such as verbal language skills, alphabet knowledge, phonological awareness, vocabulary knowledge, recognition of words beginning with the same tones, recognition of words ending with the same tones, and detection of the word spoken within written words. Within the scope of mathematical skills are there concepts related to dimension such as big-small and skills such as recognition, naming, matching, comparing, grouping, sorting, numbers, addition, subtraction and division, modeling, geometry and spatial logic, measuring, graph formation [37]. Many studies have revealed that the support provided by the parents at home have a highly critical role on the child's early academic skills [5-6-11-18-24-26-33]. In the literature, it is seen that the relationships between the support provided by the parents at home and literacy skills [1-2-12-19-23-30]; social skills [14-36-38], interpersonal skills [22] and math skills [20-21] have been investigated. Yet, only one study focusing on the effect of the support provided by the parents at home on early academic skills (language and math skills) has been found in the literature [13]. In the study, instead of evaluating the existing activities offered to the child by the parents at home, parent participation was achieved by sending sample activities. As a result of the study, it was determined that parents were limited to the sample activities and did not produce any new activities related to language and mathematics. The researcher proposed this finding as the reason for the lack of difference between the language and math scores of the control group children and those of the experimental group children.

As there is a limited amount of research investigating the relationships between early academic skills and the encouragement provided by the parents at home, the tools used to evaluate the existing applications at home are generally limited to evaluation of early literacy and there is a paucity of tools to simultaneously explore the frequencies of conducting reading and math activities at home, the current study aims to perform the adaptation of the Encouragement of Academic Skills of Young Children (EASYC) Scale into Turkish. Evaluation of the extent to which reading and math activities are carried out at home is believed to make important contributions to the literature in terms of identification of children's needs, determination of the means of the intervention tailored to a particular child, provision of support for the shortcomings in the family, fortification of parents-teacher cooperation and investigation of the effect of parent support on the development of the child.

\section{Method}

\subsection{Sampling of the Study}

The universe of the study is comprised of 48-84 months old children attending early childhood education institutions in the city of Aksaray and their parents. The sampling; on the other hand, was determined by means of convenience sampling technique. In this connection, the research permission taken was shared with the directors of the early childhood education institutions in the city of Aksaray, then schools wanting to participate in the study on a volunteer basis were determined and three schools which have the most convenient transportation were selected from among these schools. A total of 124 children aged at 48-84 months in these three schools constituted the sampling. Some demographic features of the children and their parents are given in Table 1. 
Table 1. Demographic features of the participating children and their parents

\begin{tabular}{|c|c|c|}
\hline Demographic features & f & $\%$ \\
\hline \multicolumn{3}{|l|}{ Gender } \\
\hline Girl & 60 & 48.4 \\
\hline Boy & 64 & 50.8 \\
\hline \multicolumn{3}{|l|}{ Age } \\
\hline 48-60 months & 28 & 23.4 \\
\hline $60-72$ months & 48 & 38.7 \\
\hline $72-84$ months & 47 & 37.9 \\
\hline \multicolumn{3}{|l|}{ Order of birth } \\
\hline The eldest & 19 & 14.5 \\
\hline The youngest & 62 & 50 \\
\hline Single & 30 & 24.2 \\
\hline Middle & 13 & 11.3 \\
\hline \multicolumn{3}{|c|}{ The state of having taken early childhood education before } \\
\hline Yes & 47 & 38 \\
\hline No & 77 & 62 \\
\hline \multicolumn{3}{|l|}{ The length of prior early childhood education } \\
\hline First time & 77 & 62 \\
\hline 1 year & 30 & 24.2 \\
\hline 2 years & 12 & 9.7 \\
\hline 3 years & 5 & 4 \\
\hline \multicolumn{3}{|l|}{ The person who fills in the scale } \\
\hline Mother & 106 & 85.5 \\
\hline Father & 13 & 10.5 \\
\hline Others & 5 & 4 \\
\hline \multicolumn{3}{|l|}{ People living at home } \\
\hline Mother and child & 1 & .8 \\
\hline Mother, father and child & 117 & 94.4 \\
\hline Others & 6 & 4.8 \\
\hline \multicolumn{3}{|l|}{ Number of children at home } \\
\hline One & 29 & 23.4 \\
\hline Two & 54 & 43.5 \\
\hline Three & 33 & 26.6 \\
\hline Others & 8 & 6.5 \\
\hline \multicolumn{3}{|l|}{ Mother's education level } \\
\hline Elementary school & 21 & 16.9 \\
\hline Secondary school & 22 & 17.7 \\
\hline High school & 31 & 25 \\
\hline Vocational school of higher education & 8 & 6.5 \\
\hline University & 41 & 33.1 \\
\hline Post-graduate & 1 & .8 \\
\hline \multicolumn{3}{|l|}{ Father's education level } \\
\hline Elementary & 13 & 10.5 \\
\hline Secondary school & 18 & 15.3 \\
\hline High school & 38 & 30.6 \\
\hline Vocational school of higher education & 8 & 6.5 \\
\hline University & 42 & 33.9 \\
\hline Post-graduate & 3 & 2.4 \\
\hline
\end{tabular}


It is seen that the distribution of the children in the sampling displays an even pattern in terms of age and gender. It was determined that more than half of the children had not received early childhood education before $(62 \%)$. Half of the children are the youngest in the family. Most of the data collection tools employed in the study were filled in by mothers $(85 \%)$. Nearly all of the children are raised in a nucleus family (94\%). The university graduate mothers and fathers make up $34 \%$ of the mother and father's sampling.

\subsection{Data Collection Tools}

Encouragement of Academic Skills of Young Children (EASYC): The current study employed the Encouragement of Academic Skills of Young Children (EASYC) developed by [17]. EASYC was prepared to explore the extent to which children's early academic skills are supported at home. The scale was translated to Turkish as Çocukların Evde Akademik Becerilerinin Desteklenmesi Ölçeği (ÇEABD). In the original scale, there are 42 items requiring different responding (Yes/No, 3-point Likert and 4-point Likert items). The opinions of three measurement and evaluation experts were taken about this structure of the scale requiring different responding. The shared opinion of the experts is that these three different types of scoring should be considered separately. The experts stated that the researcher should decide which part of the scale needs to be adapted parallel to the research question addressed. In this way, it was decided to adapt the third part of the scale including four-point Likert type items ranging from the 15 th item to the 42 nd item aiming to evaluate how frequent children do activities related to math and reading at home. This part of the scale consists of two sections, being reading and math sections. EASYC Reading includes the sub-dimensions of Letters and Words (4 items, $\alpha=.72$ ), Comprehension ( 4 items, $\alpha=.74$ ), Library ( 2 items, $\alpha=.57$ ), EASYC Mathematics include the sub-dimensions of Formal Math Activities ( 7 items, $\alpha=.77$ ), Informal Mathematics Activities (6 items, $\alpha=.67$ ) and Games/Toys (5 items, $\alpha=.68$ ). The Reading and Mathematics parts of the scale can be separately scored or a total EASYC score can be calculated by summing the scores taken from these parts. Reliability coefficients for the sub-dimensions of EASYC are given in the findings section.

The Home Literacy Activities Questionnaire: The Home Literacy Activities originally developed by [29] was adapted to Turkish by [1]. The Turkish version of the scale is comprised of 45 items and two sub-dimensions. The dimensions are called as Structured Activities (22 items) and Unstructured Activities (23 items). The scale is filled in by the child's parents. Each item is scored in two different ways. In the first column next to the item, it is asked to families "How important is it to perform this activity together with your child?". This item is scored as
Not very important (1), Partially important (2), Very important but not very necessary (3), Very important and very necessary (4)". In the second column is there the item "How often do you perform this activity together with your child?". This item is scored as; "Rarely or never (0)"; "Once or twice a month (1)"; "Once or twice a week (2)", "Three times or more a week (3)". For the whole of the scale, Cronbach alpha reliability coefficient was calculated to be .97 .

\subsection{Data Analysis}

Within the validity study of the ÇEABD scale, language, content, construct and criterion validities were tested. Within the context of the construct validity, explanatory and confirmatory factor analyses of the scale were conducted. In order to test the criterion validity, the correlation between the scale and the Home Literacy Activities Questionnaire was elicited through Pearson correlation analysis. Within the context of the reliability study, internal consistency coefficient and item total correlation calculation methods were used. Descriptive analysis was conducted on the scores taken by the children from the ÇEABD Scale.

\section{Findings}

\subsection{Findings Related to the Validity of the Scale}

\subsubsection{Language and Content Validity}

The translation of the scale into Turkish and its reverse translation were performed by three different early childhood education experts. The English and Turkish versions of the scale were sent to five parents who have children in early childhood period and who have a good competence of English language at different times. Then these forms were collected and analyzed and this analysis revealed that the parents scored the forms in two different languages in the same way. Four early childhood education experts agreed that the scale has the content validity.

\subsubsection{Construct Validity}

Factor analysis was applied to test the construct validity of the scale. In order to be able to conduct this analysis, first Kaiser-Mayer-Olkin (KMO) technique was used to decide whether the data set is large enough. Exploratory factor analysis was independently conducted for the two parts of the scale (Reading and Math).

$\mathrm{KMO}$ value for the reading part of ÇEABD was found to be .77 . When KMO value is between 0.7 and 0.8 , then the sampling size is considered to be good (Hutcheson and Sofroniou, 1999 cited in [31]. Barlett's Test of Sphericity value was found to be significant. At this point, it was attempted to determine whether the scale measures the target construct. In order to evaluate the suitability of the 
items in the scale, as the factor loading value, .30 was taken as the criterion. In this regard, as the items 1 and 2 did not exhibit a normal distribution, they were discarded from the scale. These items were found to be two items in the library sub-dimension (1. Attend a story time at a library or bookstore, 2. Read books checked out from the library). Given that the reliability of this sub-dimension in the original scale is at a medium level, the items in this sub-dimension were also found to be not working well in the Turkish sampling. This may be because using library is not widespread in our culture. In the construct emerging as a result of the principal components analysis conducted by means of Varimax rotation method on the remaining 8 items, two factors with an eigenvalue higher than 1 appeared. While the first factor explains $35.930 \%$ of the variance, the second factor explains $55.369 \%$ of it. These two factors were named as "letters and words" and "comprehension" as in [17]. The distribution of the items across the factors is seen in Table 2 reflecting the factor rotation results.

Table 2. ÇEABD Reading Factor Rotation Results

\begin{tabular}{|c|c|c|}
\hline Items & $\begin{array}{c}\text { Factor } \\
\text { I }\end{array}$ & $\begin{array}{c}\text { Factor } \\
\text { II }\end{array}$ \\
\hline Factor: Letters and Words & & \\
\hline Use pre reading computer software &, 880 & \\
\hline Do alphabet workbooks or worksheets &, 642 & \\
\hline Drawings with crayons or markers &, 492 & \\
\hline Ask how to spell words &, 479 & \\
\hline Factor: Comprehension & & \\
\hline $\begin{array}{c}\text { Listen to stories read by parents or } \\
\text { grandparents }\end{array}$ & &, 726 \\
\hline Play word-rhyming games & &, 684 \\
\hline Practice writing his or her name & &, 683 \\
\hline Trace or copy words on paper & &, 667 \\
\hline
\end{tabular}

Following the explanatory factor analysis, it was determined that the ÇEABD Reading consists of two sub-dimensions and 8 items in the Turkish sampling.

$\mathrm{KMO}$ value for the ÇEABD Mathematics was calculated to be .87 . When KMO value is between 0.8 and 0.9 , it can be said that the sampling size is very good (Hutcheson and Sofroniou, 1999, cited in [31]. Barlett's Test of Sphericity value was found to be significant. Similar to the Reading part, as a factor loading value, .30 was taken as the criterion to evaluate the suitability of the items in this part. In this way, as the Item 10 (Practice writing numerals 1-10 and beyond) did not exhibit normal distribution, it was excluded from the scale. In the construct emerging as a result of the principal components analysis conducted by means of Varimax rotation method on the remaining 17 items, three factors with an eigenvalue higher than 1 appeared. The first factor explains $21.121 \%$ of the variance, the second factor explains $40.791 \%$ of the variance and the third factor explains $53.429 \%$. These three factors match with the original scale's structure [17]. These factors are named; similar to the ones in the original scale, as "formal math activities", "informal math activities" and "games/toys". The distribution of the items across the factors is shown in Table 3 reflecting the results of factor rotation.

Table 3. ÇEABD Math Factor Rotation Results

\begin{tabular}{|c|c|c|c|}
\hline Items & $\begin{array}{c}\text { Factor } \\
\text { I }\end{array}$ & $\begin{array}{c}\text { Factor } \\
\text { II }\end{array}$ & $\begin{array}{c}\text { Factor } \\
\text { III }\end{array}$ \\
\hline \multicolumn{4}{|c|}{ Factor: Formal Math Activities } \\
\hline $\begin{array}{l}\text { Playing made-up games involving } \\
\text { math }\end{array}$ & ,671 & & \\
\hline $\begin{array}{l}\text { Practice adding and subtracting } \\
\text { single-digit numbers }\end{array}$ & ,732 & & \\
\hline $\begin{array}{l}\text { Watching TV shows or videos that } \\
\text { teach math }\end{array}$ & ,704 & & \\
\hline Use math in home routines & ,613 & & \\
\hline $\begin{array}{l}\text { Do math related workbooks or } \\
\text { worksheets }\end{array}$ & ,621 & & \\
\hline $\begin{array}{c}\text { Use math software on the } \\
\text { computer }\end{array}$ & ,716 & & \\
\hline \multicolumn{4}{|c|}{ Factor: Informal Math Activities } \\
\hline Do origami or paper cutting & & ,348 & \\
\hline $\begin{array}{l}\text { Do art activities involving patterns } \\
\text { and symmetry }\end{array}$ & &, 556 & \\
\hline Reading counting or shape books & &, 537 & \\
\hline $\begin{array}{l}\text { Sing or listen to songs or finger } \\
\text { plays that use math }\end{array}$ & & ,625 & \\
\hline $\begin{array}{c}\text { String beads using a repeated } \\
\text { pattern }\end{array}$ & & ,634 & \\
\hline Count actual objects or pictures & & ,646 & \\
\hline \multicolumn{4}{|c|}{ Factor: Games/Toys } \\
\hline $\begin{array}{l}\text { Play with math related board or } \\
\text { card games }\end{array}$ & & & ,416 \\
\hline $\begin{array}{l}\text { Play with math toys (shape sorters, } \\
\text { counting toys). }\end{array}$ & & &, 490 \\
\hline $\begin{array}{c}\text { Play with blocks or construction } \\
\text { toys }\end{array}$ & & &, 744 \\
\hline $\begin{array}{l}\text { Play with wooden or cardboard } \\
\text { puzzles }\end{array}$ & & & ,465 \\
\hline Play with tangrams & & &, 717 \\
\hline
\end{tabular}

Following the explanatory factor analysis, it was determined that the ÇEABD Math consists of three sub-dimensions and 17 items.

In order to evaluate the fit of the data to the factor structure, confirmatory factor analysis was run. The goodness-of-fit indices calculated with the confirmatory factor analysis for Reading are as follows: Chi Square 2.37; sd 19; CFI .92; GFI .92; NFI .88; RMSEA .013; NNFI .89; RFI .83; IFI .93; AGFI .84; RMR .06. When these values are proportioned to each other, it becomes $45.16 / 19=2.37$. As this ratio is below 3, the fit is said to be perfect [34]. RMSEA value smaller than .10 indicates a poor fit. When RMSEA value is examined, it is seen that an acceptable goodness-of-fit index at the level of .13 was obtained (Tabachnick and Fidel, 2001 cited in [9]. For NFI, NNFI, RFI, IFI, AGFI GFI indices, acceptable fit value is considered to be .90 and the perfect fit value is considered to be .95 . When these values are examined, is seen that NFI, 
NNFI, RFI, IFI values are at the acceptable level or very close to the acceptable level; GFI value is at the acceptable level; AGFI value is close to the acceptable level; CFI value is at the acceptable level. RMR value between .050 and .080 indicates a good fit (Meydan and Şeşen, 2011, Şimşek, 2007 cited in [31]. When all the values related to model- data fit are considered, it can be argued that the established model produces a high fit to the data; therefore, the scale is argued to have construct validity. The goodness-of-fit indices calculated with the confirmatory factor analysis for Math are as follows: Chi Square 208,33; sd 116; CFI .95; GFI .83; NFI .90; RMSEA .08; NNFI .94; RFI .89; IFI .95; AGFI .80; RMR .05. When these values are proportioned to each other, it becomes $208.33 / 116=1.79$. As this ratio is below 3 , the fit is said to be perfect [34]. The acceptable limit for RMSEA is determined to be between .05 and .08 . This value is .08 here indicating an acceptable goodness-of-fit index (Tabachnick and Fidel, 2001 cited in [9]. For NFI, NNFI, RFI, IFI, AGFI GFI indices, acceptable fit value is considered to be .90 and the perfect fit value is considered to be .95 . When these values are examined, is seen that NFI, NNFI, RFI, IFI values are at the acceptable level or perfect level; GFI value is at the acceptable level; AGFI value is close to the acceptable level; CFI value is at the acceptable level. RMR value between .050 and .080 indicates a good fit (Meydan and Şeşen, 2011; Şimşek, 2007 cited in [31]. When all the values related to model- data fit are considered, it can be argued that the established model produces a high fit to the data; therefore, the scale is argued to have construct validity.

\subsubsection{Criterion Validity}

For the criterion validity of ÇEABD, a sampling comprised of 51 children aged 60-75 months and their families were constructed by means of convenience sampling technique. This sampling was easy to access as the teachers voluntarily accepted to help for the delivery of the data collection tools to the families, the school director supported the research, the school was located in the city where the researchers lived, the researchers had some information about the district where the school was located and transportation to school was easy and cheap. Some demographic features of this sampling are given in Table 4 .

It is seen that a large proportion of the children in the sampling are the youngest children of the family ( $45 \%)$, are taking early childhood education for the first time (64\%) and live in a nucleus family ( $80 \%)$.

For the criterion validity, a similar scale, the Home Literacy Activities Questionnaire was used. The scale consists of two sub-dimensions, being structured and unstructured activities. In Table 5, the results of the analysis conducted to evaluate the correlation between the scores for the sub-dimensions of the Home Literacy Activities Questionnaire and ÇEABD Math and ÇEABD Reading scores are given.
Table 4. Demographic features of criterion validity sample

\begin{tabular}{|c|c|c|}
\hline Demographic features & $\mathbf{F}$ & $\%$ \\
\hline \multicolumn{3}{|l|}{ Gender } \\
\hline Girl & 31 & 60.8 \\
\hline Boy & 20 & 39.2 \\
\hline \multicolumn{3}{|l|}{ Order of Birth } \\
\hline The eldest & 9 & 17.6 \\
\hline The youngest & 23 & 45.1 \\
\hline Single & 10 & 19.6 \\
\hline Middle & 9 & 17.6 \\
\hline \multicolumn{3}{|l|}{$\begin{array}{c}\text { The State of Having Taken Early Childhood } \\
\text { Education }\end{array}$} \\
\hline Yes & 19 & 35.3 \\
\hline No & 32 & 64.7 \\
\hline \multicolumn{3}{|l|}{ Length of Prior Early Childhood Education } \\
\hline For the first time & 32 & 64.7 \\
\hline 1 year & 14 & 27.5 \\
\hline 2 years & 4 & 7.8 \\
\hline \multicolumn{3}{|l|}{ The Person Who Fills in the Scale } \\
\hline Mother & 39 & 76.5 \\
\hline Father & 8 & 15.7 \\
\hline Others & 4 & 7.8 \\
\hline \multicolumn{3}{|l|}{ People Living at Home } \\
\hline Mother, father and child & 41 & 80.4 \\
\hline Others & 10 & 19.6 \\
\hline \multicolumn{3}{|l|}{ The Number of Children at Home } \\
\hline One & 29 & 23.4 \\
\hline Two & 54 & 43.5 \\
\hline Three & 33 & 26.6 \\
\hline Others & 8 & 6.5 \\
\hline \multicolumn{3}{|l|}{ Mother's Education Level } \\
\hline Illiterate & 1 & 2 \\
\hline Elementary school & 12 & 23.5 \\
\hline Secondary school & 12 & 23.5 \\
\hline High school & 13 & 25.5 \\
\hline Vocational School of Higher Education & 5 & 9.8 \\
\hline University & 8 & 15.7 \\
\hline \multicolumn{3}{|l|}{ Father's Education Level } \\
\hline Elementary School & 12 & 23.5 \\
\hline Secondary School & 5 & 9.8 \\
\hline High School & 16 & 31.4 \\
\hline Vocational School of Higher Education & 4 & 7.8 \\
\hline University & 13 & 25.5 \\
\hline
\end{tabular}

Table 5. The results of the correlation analysis related to the relationship between ÇEABD Math and ÇEABD Reading scores and the Home Literacy Activities Questionnaire sub-dimension scores

\begin{tabular}{|c|c|c|c|c|c|}
\hline Home Literacy Activities Q. & \multicolumn{2}{|c|}{ ÇEABD Math } & \multicolumn{2}{c|}{ ÇEABD Reading } \\
\hline & F. & I. & G/T & LW & C \\
\hline Str. Act. & .794 & $.012 * *$ & $.048^{*}$ & $.048^{*}$ & $.000^{* *}$ \\
\hline Unstr. Act. & .982 & $.000^{* *}$ & $.033^{*}$ & .478 & $.002^{* *}$ \\
\hline
\end{tabular}

$\mathrm{n}=51, * * \mathrm{p}<.01 ; * \mathrm{p}<.05$

When the correlation values are examined, it is seen that there is a positive and significant correlation between the scores taken from the structured activities sub-dimension of the Home Literacy Activities Questionnaire and ÇEABD_Math Informal and ÇEABD_Reading 
Comprehension scores $\quad(\mathrm{p}<.01)$ and ÇEABD_Math Games/Toys and ÇEABD_Reading Letters and Words scores $(\mathrm{p}<.05)$. There is a positive and significant correlation between the scores taken from the unstructured activities sub-dimension of the Home Literacy Activities Questionnaire and ÇEABD_Math Informal and ÇEABD_Reading Comprehension $(\mathrm{p}<.01)$ and ÇEABD_Math Games/Toys scores $(\mathrm{p}<.05)$.

\subsection{Findings Related to the Reliability of the Scale}

Within the context of the reliability study of the scale, Cronbach alpha internal consistency coefficients and item total correlation coefficients were calculated for ÇEABD Reading and ÇEABD Math. The internal consistency coefficients for the sub-dimensions of ÇEABD Reading are as follows: Letters and Words .70, Comprehension .72. The internal consistency coefficient for the whole ÇEABD Reading is .80. The internal consistency coefficients for the sub-dimensions of ÇEABD Math are as follows: Formal Math Activities .78, Informal Math Activities .77 and Games/Toys .76. The internal consistency coefficient for the whole of ÇEABD Math is .90 . The total correlation values of the items vary between .514 and .632 for Formal Math Activities; between .416 and .697 for Informal Math Activities; between .467 and .644 for Games/Toys; between .478 and .561 for Letters and Words; between .453 and .681 for Comprehension. The findings of the reliability analysis proved that the ÇEABD Scale is reliable in the Turkish sampling.

\subsection{Findings Related to the Descriptive Analysis of ÇEABD Scale}

Means, Standard Deviations, Lowest and Highest Values for the Children's ÇEABD Scale are given in Table 6,7 and 8 .

Table 6. Means, Standard Deviations, Lowest and Highest Values for the Children's ÇEABD Reading Sub-Dimension Scores and Total Scores

\begin{tabular}{|c|c|c|c|c|c|}
\hline $\begin{array}{c}\text { ÇEABD } \\
\text { Reading }\end{array}$ & $\mathbf{N}$ & Lowest & Highest & Mean & $\begin{array}{c}\text { St. } \\
\text { Deviation }\end{array}$ \\
\hline $\begin{array}{c}\text { Letters and } \\
\text { Words }\end{array}$ & 124 & 4 & 16 & 9,42 & 2,592 \\
\hline Conception & 124 & 4 & 16 & 9,76 & 2,912 \\
\hline Total & 124 & 8 & 32 & 19,18 & 4,947 \\
\hline
\end{tabular}

The children's reading sub-dimension and total mean scores are at the medium level.

Table 7. Means, Standard Deviations, Lowest and Highest Values for the Children's ÇEABD Math Sub-dimension Scores

\begin{tabular}{|c|c|c|c|c|c|}
\hline $\begin{array}{c}\text { ÇEABD } \\
\text { Math }\end{array}$ & N & Lowest & Highest & Mean & $\begin{array}{c}\text { St. } \\
\text { Deviation }\end{array}$ \\
\hline F & 124 & 6 & 24 & 13.87 & 3.685 \\
\hline I. & 124 & 8 & 24 & 15.85 & 3.649 \\
\hline G/T & 124 & 5 & 20 & 14.08 & 3.094 \\
\hline Total & 124 & 22 & 65 & 43.80 & 9.302 \\
\hline
\end{tabular}

When ÇEABD math scores are examined, it is seen that sub-dimension and total mean scores are at the medium level.

Table 8. Means, Standard Deviations, Lowest and Highest Values for the Children's ÇEABD Total Scores

\begin{tabular}{|c|c|c|c|c|c|}
\hline $\begin{array}{c}\text { CCEABD } \\
\text { Total }\end{array}$ & N & Lowest & Highest & Mean & $\begin{array}{c}\text { St. } \\
\text { Deviation }\end{array}$ \\
\hline & 124 & 30 & 93 & 62.98 & 13.662 \\
\hline
\end{tabular}

When Table 8 is examined, it is seen that the children's ÇEABD total score mean is at the medium level.

\section{Discussion and Results}

In the current study, it was tested whether the EASYC scale used to determine how frequent children perform activities related to reading and math at home is a valid and reliable scale in the Turkish sampling. The findings obtained from the analyses revealed that the EASYC's Turkish version, ÇEABD, can be used as a valid and reliable measurement tool in the Turkish sampling.

Expert opinions verified that the ÇEABD Scale satisfies language and content validity. As a result of the explanatory factor analysis conducted within the context of construct validity, the items in the first part of the scale; that is in the Reading part, exhibited a distribution across two dimensions as different from the original scale. In the third dimension of the original scale, there are items related to use of library. The reason for these items' not showing a normal distribution in the Turkish sampling might be the fact that use of library resources is not too common among Turkish. Indeed, Ekici [10] found that due to lack of finance, libraries in Turkey cannot offer wide variety of materials, services provided for children by libraries are limited and there are not enough library activities to make libraries attractive, effective and interesting. All the items except for this dimension that does not work in the Turkish sampling are subsumed under the sub-dimensions of Letters and Words and Comprehension as in the original of the scale. The goodness-of-fit indices obtained as a result of the confirmatory factor analysis proved that this construct having two sub-dimensions was confirmed in the Turkish sampling. The results of the factor analysis conducted for the second part of the scale; that is the Math part, revealed that the items showed distribution across three dimensions similar to the original scale. One item was excluded from the scale as it did not show any distribution. This item is "practice writing numerals $1-10$ and beyond" and high majority of the children (87\%) do not this activity at home. The reason for this item not working in the Turkish sampling might be that the objectives in the early childhood education program such as "Forward and backward rhythmic counting", "Showing how many objects are referred by a number", "Saying the number of the objects counted", "Saying ordinal numbers", "Saying 
what comes before and after a number up to 10 "focus on oral production rather than written production [28]. Families who are aware of this focus at school may have also concentrated on oral production at home. The items aside from these items exhibited distribution across the sub-dimensions of Formal Math Activities, Informal Math Activities and Games/Toys. The goodness-of-fit indices obtained as a result of the confirmatory factor analysis revealed that this construct with three sub-dimensions was confirmed in the Turkish sampling.

Within the context of the analysis conducted in relation to the criterion validity of the scale, 51 children were selected and their scores for the Home Literacy Activities Questionnaire proved to be a valid and reliable measurement tool in the Turkish sampling and similar to ÇEABD were calculated. Between the scores taken from this scale by the children and those taken from the ÇEABD Scale, positive and significant correlations were found considering their sub-dimensions.

As a result of the reliability analysis of the scale, the Cronbach alpha internal consistency coefficients for the sub-dimensions and the whole of the scale were found to be at the acceptable level. Büyüköztürk [8] stresses that items having 0.30 or higher item total correlation discriminate individuals well. When the item total correlation values in relation to the sub-dimensions are examined, it is seen that the discriminatory power of the items is good.

When the findings obtained from the descriptive analysis of CCEABD were examined, it was found that the children's mean scores for the ÇEABD reading and math sub-dimensions are at the medium level. Thus, it can be maintained that the parents in the study group moderately support their children to perform activities related to the sub-dimensions of letters and words, comprehension, formal math, informal math and games/toys at home. The research shows that supporting children's math and reading skills at home has positive effects on their learning [3-16-24-25-26-32-40]. Wood [40] found that performing activities requiring mother/father-child interaction at home had positive effects on the children's reading achievement, vocabulary repertoire, memory and phonologic awareness. Senechal and LeFevre [32] proved that introducing books to children at home during the early childhood period contributed to the development of their listening skill and vocabulary repertoire during their elementary education. Lefebvre, Tredeau and Suttun [25] found that reading books aloud had positive effects on spelling awareness and letter recognition. Anders et al. [3] determined that performing activities by providing learning environments for children to work on numbers and reading and writing had positive effects on their learning math. Kleemans, Peeters, Segers and Verhoeven [24]; similarly, reported that doing exercises on numbers at home positively affected children's accomplishment of the objectives related to numbers. LeFevre et al. [26] pointed out that informal activities performed at home during the early childhood period (measuring and calculating during cooking, card games, table games) predict the math achievement in the following years.

All this research clearly shows the importance of supporting education at home and underlines the importance of evaluating the extent of the support at home by means of valid and reliable measurement tools. Thus, researchers can explore the extent to which early academic skills of children at different age groups and with different demographic features are supported at home especially during the early childhood period, can develop ways of intervention to enhance this support and can elicit the relationships between this support and reading/math achievement in the following years, executive function skills etc. by using the ÇEABD Scale whose validity and reliability have been established. On the basis of the finding that the parents of the children in the sampling moderately support their children at home, parents can be given training to raise their awareness of the importance of the education support at home in terms of the accomplishments of their children. Teachers can provide sample activities to guide parents about how to support their children at home.

\section{REFERENCES}

[1] Altıparmak, S. Erken Çocukluk Döneminde Ebeveynlerin Okuma-Yazmaya Hazırlı Konusundaki Görüşleri. Yayınlanmamış yüksek lisans tezi, Orta Doğu Teknik Üniversitesi, Ankara, 2010.

[2] Altun, D. Okul Öncesi Dönemi Çocuklarının Okumaya Karşı Tutumları ile Ev İçi Okuryazarlık Ortamının İlişkisinin Araştırılması. Yayınlanmamış Yüksek Lisans Tezi, Orta Doğu Teknik Üniversitesi, Ankara, 2013.

[3] Anders, Y., Rossbach H.G., Weinert, S., Ebert, S., Kuger, S., Lehrl, S. et al. Home and preschool learning environments and their relations to the development of early numeracy skills. Early Childhood Research Quarterly, 27, 231-244, 2012.

[4] Atak, H. Piaget ve Vygotsky'nin kuramlarında çocukların toplumsallaşma süreci. Psikiyatride Güncel Yaklaşımlar, 9 (2):163-176, 2017.

[5] Bennett, K., Weigel, D., \& Martin, S. Children's aqusition of early literacy skills: Examining family contributions. Early Childhood Research Quarterly, 17, 295-317, 2002.

[6] Blevins-Knabe, B., Berghout Austin, A., Musun, L., Eddy, A., \& Jones R. M. Family home care providers' and parents' beliefs and practices concerning mathematics with young children. Early Childhood Development and Care, 165, 41-58, 2000.

[7] Bronfenbrenner; U. The ecology of human development. Cambridge, MA: Harvard University Press, 1979.

[8] Büyüköztürk, Ş. Sosyal bilimler için veri analizi el kitabı, Ankara: Pegem A Yayıncılık, 2007. 
[9] Çokluk, Ö, Şekercioğlu, G. \& Büyüköztürk, S.., Sosyal Bilimler Iç̧in Çok Değişkenli Ístatistik: SPSS ve LISREL Uygulamaları. (2.bask1). Ankara: Pegem Akademi Yayincilık, 2013.

[10] Ekici, S. Ankara'da Bulunan Halk Kütüphanesi Çocuk Bölümlerinin Değerlendirilmesi. 2. Halk Kütüphaneciliği Sempozyumu: Değişen Dünyada Halk Kütüphaneleri, Bodrum, 2012.

[11] Fantuzzo, J., McWayne, C., Perry, M. A., \& Childs, S. Multiple dimensions of family involvement and their relations to behavioral and learning competencies for urban, low-income children. School Psychology Review, 33 (4), 467-480, 2004

[12] Güleç, N., \& İvrendi, A. 5-6 yaş çocuklarının sayı kavramı becerilerinin ebeveyn ve öğretmen değişkenleri açısından yordanması. Hacettepe Üniversitesi Eğitim Fakültesi Dergisi, 32(1): 81-98, 2017.

[13] Günay Bilaloğlu, R. Okul Öncesi Eğitimde Aile Katılımı Etkinliklerinin Uygulanmasında Karşılaşılan Sorunlar ve Aile Katılımı Etkinliklerinin Dil-Matematik Becerilerinin Geliştirilmesine Etkisi. Yayınlanmamış Doktora Tezi, Çukurova Üniversitesi, Adana, 2014.

[14] Gürșimșek, I., Girgin, G., Harmanlı, Z. \& Ekinci, D., Çocuğun Eğitiminde Aile Katılımının Önemi (Bir Pilot Çalışma). Erken çocukluk gelişimi ve eğitimi sempozyumu bildiri kitabı. Ankara: Kök Yayıncılık, 2002.

[15] Hamamcı, Z. \& Hamamcı, E. Çocuk gelişimi kuramları ve dil öğretmenleri için yansımaları. Ĕgitim ve Öğretim Araștırmaları Dergisi, 4 (1), 125-134, 2015.

[16] Huntsinger, C. S., Jose, P. B., Liaw, F.-R., \& Ching, W. D. Cultural differences in early mathematics learning: a comparison of Euro-American, Chinese-American, and Taiwan-Chinese families. International Journal Behavioral Development, 21, 371-388, 1997.

[17] Huntsinger, C. S., Jose, P. E. \& Luo, Z. Parental facilitation of early mathematics and reading skills and knowledge through encouragement of home-based activities. Early Childhood Research Quarterly 37 (2016) 1-15, 2016.

[18] Huntsinger, C. S., Jose, P. E., \& Larson, S. L. Do parent practices to encourage academic competence influence the social adjustment of young European American and Chinese American children? Developmental Psychology, 34, 747$756,1998$.

[19] Işıkoğlu Erdoğan, N. Erken çocukluk döneminde çocuk-ebeveyn birlikte okuma etkinliklerinin incelenmesi. Kastamonu Eğitim Dergisi, 24 (3), 1071-1086, 2016.

[20] İrkörücü, S. Okul Öncesi Eğitim Kurumuna Devam Eden 6 Yaşındaki Çocuklara Uygulanan Ev Odaklı Matematiksel Destek Programının Çocukların Matematiksel Kavram Edinimine Etkisinin Incelenmesi. Unpublished Master Thesis, Gazi University, Ankara, 2006.

[21] İvrendi, A. \& Wakefield, A. Mothers' and fathers' participation inmathematical activities of their young children. The 5th International Balkan Education and Science Congress, Trakya University, Edirne. 50-54, 2009.

[22] Kapusuzoğlu, Ş. 3-6 yaş arası okul öncesi sinıf yönetimi uygulamalarının ve aile desteğinin çocuğun kişilik gelişimine etkisinin değerlendirilmesi. I. Uluslararası Okul Öncesi Eğitim Kongresi içinde (III. Cilt, s. 220-229) İstanbul: Ya-Pa Yayınları, 2006.

[23] Kız1ltas, E. Okul Öncesi Eğitimde Uygulanan Aile Katılım Çalışmalarının 5-6 Yaş Grubu Çocukların Dil Becerilerinin Gelişimine Etkisi. Unpublished Master Thesis, Atatürk University, Erzurum, 2009.

[24] Kleemans, T., Peeters, M., Segers, E. \& Verhoeven, L. Child and home predictors of early numeracy skills in kindergarten. Early Childhood Research Quarterly, 27,471-477, 2011.

[25] Lefebvre, P., Trudeau, N. \& Sutton, A. Enhancing vocabulary, print awareness and phonological awareness through shared storybook reading with low-income preschoolers. Journal of Early Childhood Literacy, 11(4), 453-479, 2011.

[26] LeFevre, J. A., Skwarchuk, S. L., Smith-Chant, B. L., Fast, L., Kamawar, D. \& Bisanz, J. Home numeracy experiences and children's math performance in the early school years. Canadian Journal of Behavioural Science, 41 (2), 55-66, 2009.

[27] Meydan, C. \& Seșen, H. Yapısal Eşitlik Modellemesi AMOS Uygulamaları, Ankara: Detay Yayıncılık, 2011.

[28] Ministry of Education. Early Childhood Education Program for 60-72 Months of age children. Ankara: Ministry of Education Publications, 2013.

[29] Nebrig, M. R. Parent and Teacher Perceptions of Home Activities to Encourage Emergent Literacy. (Doctoral dissertation, Lehigh University, 2007.

[30] Özen Altınkaynak, S. Aile Temelli Okuma Yazmaya Hazırlık Programinin Çocukların Okuma Yazmaya Hazırlık Becerilerine Etkisi, Yayınlanmamış doktora tezi, Hacettepe Üniversitesi, Ankara, 2014.

[31] Seçer, İ. SPSS ve LISREL ile pratik veri analizi. Ankara: Anı Yayıncilik, 2013.

[32] Sénéchal, M. \& LeFevre, J. Parental involvement in the development of children's reading skill: A 5-year longitudinal study. Child Development, 73(2), 445-460, 2002.

[33] Skwarchuk, S. L., Sowinski, C. \& LeFevre, J. A. Formal and informal home learning activities in relation to children's early numeracy and literacy skills: The development of a home numeracy model. Journal of Experimental Child Psychology, 121, 63-84, 2014.

[34] Sümer, N. Yapısal eşitlik modelleri. Türk Psikoloji Yazıları, 3(6), 49-74, 2000

[35] Simşek, Ö. F. Yapısal Eşitlik Modellemesine Giriş Temel İlkeler ve LISREL Uygulamaları. Ankara: Ekinox, 2007.

[36] Unutkan, Ö. P. 5-6 yaş çocuklarının yaşadıkları evin yapısının ilköğretime hazır bulunuşluk düzeyine etkisi. Ondokuz Mayıs Üniversitesi Eğitim Fakültesi Dergisi, 24, 43-54, 2007.

[37] Uyanık, Ö. \& Kandır, A. Okul Öncesi Dönemde Erken Akademik Beceriler, Kuramsal Ĕgitimbilim Dergisi, 3(2), s.118-134, 2010.

[38] Vural, D. E. Okul Öncesi Programlarındaki Duyuşsal Ve 
Sosyal Becerilere Yönelik Hedeflere Uygun Olarak Hazırlanan Aile Katılıml Sosyal Beceri Eğitimi Programinın Çocuklarda Sosyal Becerilerin Gelişimine Etkisi. Yayınlanmamış yüksek lisans tezi, Dokuz Eylül Üniversitesi, İzmir, 2006.

[39] Vygotsky, L S. Educational implications. In M. Cole, V.
John-Steiner, S. Scribner \& E. Souberman (Eds.), Mind in society: The development of higher psychological processes (pp. 79-153). Cambridge: Harvard University Press, 1978.

[40] Wood, C. Parent-child preschool activities can affect the development of literacy skills. Journal of Research Reading, 25 (3), 241-258, 2002 